\title{
The Embodiment of Indian Feminist Thought
}

\author{
Haydor Uddin
}

\author{
Swami Vivekananda Subharti University, Merut, Uttar Pradesh Department of English
}

haydoruddin2@gmail.com

\begin{abstract}
Mother of modern Indian English poetry, confessional poet, Kamala Das was born at Punnayukulam on $31^{\text {st }}$ March 1934, Thrissur District in Kerala. She was one of the most original Indo-Anglican poets. She made a high position in Indian English poetry. And her poetry is considered the poetry of introspection and self-analysis. No doubt, she made a mark as a female Indo-Anglican poet. Verily, she has achieved greatness as a poet not only because of the contents of her poems but also because of her technique of writing poetry. And it would never be overstatement if it is said that she was a voice of Indian women. She has certainly made a name for herself by virtue of her craftsmanship. So, in this research article research, researcher attempted to display Kamala Das's greatness and her poetic style. And also, this article deals that how she expressed herself openly without any pause specially focusing on the expression and problematization of gender roles in her works. In this research article, secondary sources have been used.
\end{abstract}

Keywords: Poetic Style, Literary Device, Technic of Writing, Theme of Poetry, Heart-voice, Confessional Poet

\section{Kamala Das's Poetry}

Kamala Das is primarily a poet of feminine longings and feminist voice in postcolonial era. She wrote poems on various topics such as love, protest and so forth. She has spoken and written about a variety of themes related to love, hatred, sacrifice, treason and an enduring pursuit of true love. In some of her poems, she's restless and disturbed. There's a trishna she wants to meet Lord Krishna through her poetry. Maya Angelou said, "There is no more agony than to have an untold story within you. " Kamala Das tried to unveil her untold truth, emotions, and feelings through her poems of love and protest in particular'. Her poetry reflects her restlessness as a sensitive woman moving in the maledominated society, and in them she appears as a champion of woman's cause'. She raises her forceful voice against the male tyranny in her poetry.

And her poetical collections in English are: Summer in Calcutta, The Descendants, and The Old Playhouse and other poems. The poetry of Kamala Das provide the testimony of being autobiographical because it expounds her hardship sufferings which is tortured, complexion of woman's sensibility. Her poetry is the result of her childhood experience that she considers herself miserable and "a misfit everywhere". It is confessional poetry through which she expresses explicitly her humiliations. Hari Mohan Prasad has aptly taken notice about Kamala Das's poetic works: Her poetry has often been considered as a gimmick in sex or striptease in words, an over expose of body or "snippets of trivia". But the truth is that her poetry is an autobiography, an articulate voice of her ethnic identity, her Dravidian culture. In her, the poetry is fully obliterating Eliot's distinction between the man suffering and the mind creating. She has also been likened to literary greats like Sylvia Plath because of the confessional style of her writing. And the very interested this that though she never formally associated herself with the feminist movement or described herself as one, she was a feminist in many ways which can be seen in her works specially in her poetry. She never let anyone deter her from doing what she wanted to do by constantly rebelling against the system with her work. She created for herself a space to have the freedom of choice. She dared to find her voice in a society that actively tried to shut it down and she used that voice to express her experiences of the feminine sensibility that were universal in many ways. This makes her fiercely feminist in every sense of the word.

Kamala Das is quite open and frank about her feelings. She is one of the very few poets who talks so openly of her passion. All poems of Kamala Das are her quest identity in traditional society. 'An Introduction' an autobiographical poem by Kamala Das, deals with feminine sensibility. In the poem, she introduces herself as typical brown color Indian. The obsession with love is one of the prominent features of her poetry. The failure to arrive at its highest point leaves her wounded. There are some poems such as 'The Freaks', 'The Old Playhouse', and 'An Introduction'. 'The Looking Glass' which is not only the mirror of her hurt-self but also shows her struggle to achieve identity and individualism. The confessional poems depend upon the honesty of the writer and Kamala Das has justified it by being self in her poetic works. Some of her confessions about various love episodes have shocked the readers and the critics both. It is stranger because such kind of poetry is coming from an Indian woman who is mostly considered to be shy, silent and introvert.

Kamala Das through her poetry not only expresses the inner feelings but she also projects herself as a feminist poetic voice who is always asking for a dignified place of honour. As Indian women poets show a sensitive awareness of their milieu and seeking certain corrective measures for the historical wrong done to womanhood. All this leads to the crisis of identity.

As a confessional writer, there is a characteristic tendency in her two plays "the literal self-more and more at the centre of the poem" (Rosenthal 27). For the proper understanding of her poetry, a psycho biographical approach cannot be all together ruled out. We shall have appropriate feedback of her personal life, her loneliness and romantic intimations of morality, while studying the love life of Kamala Das. At various occasions, death seems an easy escape for her from the loneliness of life. She was haunted by the idea of suicide because death seems like a mystical experience which she finds desirable because life is not going to be made new. Das's poetry is most convincing to those readers who approach it to identify themselves with the inner sight of the 
poet and see the world through the eyes of a haunted woman. Most of her poetry concerns itself with the poet's intensely felt need for declaring her autobiography to the world. Her poetry is all about herself, about her desire for love, her emotional involvement and her failure to achieve such a relationship. Her poetry is crisscrossed by soul searching, self-analysis, introspection and looking deep into oneself, which is why she is called one of the best Indian English woman poets of modern times.

\section{Poetic Style of Kamala Das}

\section{Mastery of English Language}

A command of the English language is naturally the first requirement of an Indo-Anglican poet. Kamala Das's command over English language deserves to be admired. This command has duly been recognized by most of the scholars. She has a vast range of vocabulary. She understands the precise meanings of words. She can differentiate between the shades of meanings. We may take any poem by Kamala Das, and we shall find evidence of her command on the English language.

\section{Choice of Words and Phrases}

Kamala Das deserves high praise for her choice of words and for combining those words into phrases, clauses and sentences.

In the choice of words, she exercises a special care. Her words are neither splendid nor glittering. According to the requirements of the poem, Kamala Das is able to use simple and tough words. She is a poet in the confessional mode and thus her tone is conversational and her diction is often colloquial. The words come to her effortlessly and become one with emotions. Kamala Das reveals a mastery of phrases also. Here is an example of her use of words: Cowering Beneath your monstrous ego I ate the magic Became a dwarf. [The Old Playhouse].

Repetition of Words: One of the stylistic devices employed by Kamala Das is the frequent repetition of words, lines and even sections of a poem. It emphasizes an idea or an emotion. Repetition of words works well in the poem 'Substitute'. This is a device that reminds us of D. H. Lawrence and Dylan Thomas.

Mastery of Rhythm: Kamala Das's poetry reveals a control over rhythm. According to a critic her best poems display a strong feeling for rhythm. Most of her poetry is non-metrical but most of it is rhythmic. A poem entitled 'An Introduction' can be taken as an example in support of this view. This poem begins with the rhythms of conversational speech:

Be Amy, or be Kamala. Or better Still, Madhavikutty. It is time to Choose a name, a role.

Imagery: The poetry of Kamala Das abounds in imagery. Her imagery covers a wide range. It is by no means monotonous or boring. It is suggestive and functional. Her images and symbols are taken from the commonplace. They reveal the poet's own life. They fully support the theme of her poetry. In her poetry the imagery of love and sex is predominant. 'The Freaks', 'The Sunshine Cat' and 'The Old Playhouse' deal with such imagery. Some of her poems deal with the imagery of sights witnessed by the poet herself. In 'A Hot Noon in Malabar' we get a catalogue of sights. Then there is the imagery of motherhood. Her 'Jaisurya' is a fine example of it.

\section{Stylistic Shortcoming}

Some critics are of the view that Kamala Das is not a perfect artist in the use of the English language or in her craftsmanship. According to them much of her poetry is marred by her omission of punctuation marks. Due to this her poetry becomes difficult for the average reader. In the technical sense, her poems are extremely irregular and often bewildering. But this is not true to the poetry of kamala Das.

\section{Conclusion}

On the whole Kamala Das is a great poet. She was an exemplary new woman in many ways. She was bold, uninhibited, full of creative energy that she sustained to the very end as is proven by her works. Her contribution to Indo-Anglican poetry will always be remembered. It is she who has made a new path for the female poets of India. Verily, in her poetry it can be seen that she expresses inner voice of women, as we see that women are oppressed by the male-dominated or patriarchal society. She exposed the brutal behaviour of men towards women. And her writing style is quite energetic and grand style through which expressed her in a simple way. She was a great and original poet with a distinctive poetic personality of her own. When at her best, she remains unequalled and matchless. She shows remarkable command and ease over the use of English and has cultivated a style that is characterized by a colloquial simplicity and clarity. Words effortlessly come to her. Since English is most dear to her, she naturally and skillfully uses it to express her emotions, her feelings, her reminiscences, her love and sexual experiences, her frustrations and disillusionments most effectively. She was a poet who made a place in the hearts of people and will be in the heart of people forever. We lost a leader and revolutionary voice of age.

\section{References}

[1] Dr. Hareshwar Roy, "Poetic style of kamala Das" https://www.englitmail.com/2016/12/poetic-

craftsmanship-of-kamala-das.html, December 21, 2016, Access on 12 August 2021.

[2] Mina Surjit Singh, " The Confessional Voice of Kamala Das", Iqbal Kaur (ed.), Perspective on Kamala Das' Poetry (New Delhi: Intellectual Publishing House, 1995), p.87.

[3] Purnima Bali, "Poetry of Protest and Confession: A Study of Kamala Das" The Criterion, ISSN 0976-8165, 2013, p.3

[4] Devindra Kolhi, Kamala Das's Contemporary Indian Verse, ed. Kulshestha, Chirantan (New Delhi: ArnoldHeinemann), p.22-24.

[5] Nazreen Ayaz, "Concept of Love in the poetry of Kamala Das, " Iqbal Kaur (ed.), Perspective on Kamala Das's Poetry, p.109 